\title{
MULTICRITERIA OPTIMIZATION FOR DETERMINING LOW WEAR OF THE SURFACE PRODUCED IN ELECTRICAL DISCHARGE MACHINING
}

\author{
Sivaprasad P V $\mathbf{V}^{1}$, A. Mandal ${ }^{2}$ \\ ${ }^{1}$ PG Student, Department of Manufacturing Engineering, NIFFT, Ranchi, Jharkhand, India \\ ${ }^{2}$ Professor, Department of Manufacturing Engineering, NIFFT, Ranchi, Jharkhand, India
}

\begin{abstract}
Surface roughness has a significant effect on the functional performance of two mating surfaces. One of the objectives of this work is to develop mathematical models based on the design of experiments to correlate the controllable process parameters (Current, Pulse on time, Inter-electrode gap and Electrode rotation) of EDM to surface roughness parameters such as $S_{q}, S_{s k}, S_{k u}$ and $S_{H t p}$. Using Central Composite Design the desired mathematical models are developed. However, using only a single 3D roughness parameter will not be sufficient for evaluating functional performance of a surface. So, it is necessary to use multiple 3D surface parameters for characterizing the functional performance of a surface. The functional requirement such as low wear rate during service depends on a number of surface roughness parameters such as $S_{q}, S_{s k}, S_{k u}$ and $S_{H t p}$. Hence, the next objective is to use multi-criteria optimization based on desirability function to find out the value of operating parameters that will ensure low wear rate. The values of operating parameters for low wear rate for lubricated and unlubricated conditions are found. SG Iron of grade 450/12 (pearlitic matrix) is used as workpiece material as it is an important engineering material and limited information is available on machining of SG iron using EDM.
\end{abstract}

Keywords: EDM, Surface Roughness, Central Composite Design, Multi-Criteria Optimization, Desirability Function.

\section{INTRODUCTION}

The EDM process is generally used to machine very hard, high strength electrically conductive materials. Since, no cutting force is generated hence, very intricate shapes can be machined economically with high accuracy. However, there are many operating parameters that dictate the quality of the machined feature such as open circuit voltage, discharge voltage, discharge current, current pulse profile, pulse ontime, pulse off time, gap between the workpiece and the tool (spark gap), polarity of tool and workpiece, dielectric medium etc. The various models reported in the literature [1-5] correlating process parameters to surface finish of the machined surface are based on specific ranges of process parameters and particular workpiece - tool combination. The models cannot be used either for different workpiece tool combination or for different ranges of process parameters.

So for any new workpiece - tool combination or different process parameter ranges, new models need to be developed for predicting the surface finish of the machined surface.

S G Iron is increasingly being used in many industrial applications. From the automobile sector to the farm equipment this material has got a wide acceptance. It is claimed that ductile iron can replace carbon and low alloy steels. [6]

Surface roughness is often treated as an index of the product quality [7]. The surface roughness parameters may be used to explain the functional properties of the surfaces under mating [8-9]. The 2D surface parameters though used widely are not enough to explain the functionality of surfaces as the surfaces interact in three dimensions rather than in two dimensions [10]. It is found that a combination of surface roughness parameters is necessary to characterize the functional property of a surface [11-12]. Wear is reported [13] to be larger when the initial values of the amplitude parameters $S_{a}$ (Arithmetic mean deviation of the surface, $\mu \mathrm{m}$ ), $\mathrm{S}_{\mathbf{q}}$ (Root-Mean-Square deviation of the Surface, $\mu \mathrm{m})$ and $\mathrm{S}_{\mathbf{H t p}}$ (Surface section height difference $(20 \%-80 \%))$, as well as rms. slope $S_{\mathbf{D q}}$ are high. It is reported [14] that in case of dry wear test, coefficient of friction is low when roughness is high. In lubricated case, when roughness is low, then coefficient of friction is low. It is found [14] that increase in parameter $R_{k u}$ (Kurtosis of the topography height distribution-2D) led to increase in friction in lubricated case and decrease in friction for dry tests. Friction also observed to be lower when the parameter $\mathrm{R}_{\mathrm{sk}}$ tends to be more negative in lubricated tests [14].

From the above observations, constraints for the low wear conditions are developed for two cases [15].

\subsection{Un-Lubricated / Dry Case}

Maximize $S_{q}, S_{H t p}$

Minimize $S_{\text {sk }}$ (Skewness of the topography height distribution), $S_{\mathbf{k u}}$ (Kurtosis of the topography height distribution) 


\subsection{Lubricated Case}

Maximize $S_{\text {ku }}$

Minimize $S_{\mathbf{q}}, S_{\mathbf{H t p}}$ and $S_{\text {sk }}$

The primary objective is to develop second order regression equations for each surface parameter $\left(S_{\mathbf{q}}, S_{\mathbf{s k}}, S_{\mathbf{k u}}\right.$ and $\left.S_{\mathbf{H t p}}\right)$ and the secondary objective is to utilize these mathematical models for finding the optimum combination of process variables for low wear condition in both lubricated and unlubricated cases.

\section{DEVELOPMENT OF MATHEMATICAL}

\section{MODELS}

Central composite design is used to develop the mathematical models [16].The design matrix used for experimentation is a thirty point central composite design. The matrix contains four process variables (Current, Pulse on time $\left(\mathrm{T}_{\text {on }}\right)$, Inter electrode gap and Electrode rotation) at five levels $(-2,-1,0,+1,+2)$. The actual and coded values of the four process variables are given in Table- 1 and the design matrix is evinced in Table-2.

Table-1: The Actual and Coded Values of Different Variables

\begin{tabular}{|c|c|c|c|c|c|c|c|}
\hline \multirow{2}{*}{ Parameter } & \multirow{2}{*}{ Symbol } & \multicolumn{5}{|c|}{ Level } & \multirow[t]{2}{*}{ Unit } \\
\hline & & -2 & -1 & $\mathbf{0}$ & +1 & +2 & \\
\hline Current & A & 24 & 32 & 40 & 48 & 56 & amp \\
\hline $\mathrm{T}_{\text {on }}$ & B & 8 & 28 & 48 & 68 & 88 & $\mu \mathrm{s}$ \\
\hline Gap & $\mathrm{C}$ & 0.01 & 0.25 & 0.5 & 0.75 & 1 & $\mathrm{~mm}$ \\
\hline Rotation & $\mathrm{D}$ & $\mathbf{0}$ & 10 & 20 & 30 & 40 & $\mathrm{rpm}$ \\
\hline
\end{tabular}

Table-2: The Design Matrix

\begin{tabular}{|c|c|c|c|c|}
\hline Standard & $\begin{array}{l}\text { Current } \\
\text { (Amp) }\end{array}$ & $\begin{array}{l}\text { Pulse } \\
\text { On } \\
\text { Time } \\
(\mu \mathrm{s})\end{array}$ & $\begin{array}{l}\text { Inter } \\
\text { Electrode } \\
\text { Gap }(\mathrm{mm})\end{array}$ & $\begin{array}{l}\text { Rotation } \\
(\mathrm{rpm})\end{array}$ \\
\hline 1 & -1 & -1 & -1 & -1 \\
\hline 2 & 1 & -1 & -1 & -1 \\
\hline 3 & -1 & 1 & -1 & -1 \\
\hline 4 & 1 & 1 & -1 & -1 \\
\hline 5 & -1 & -1 & 1 & -1 \\
\hline 6 & 1 & -1 & 1 & -1 \\
\hline 7 & -1 & 1 & 1 & -1 \\
\hline 8 & 1 & 1 & 1 & -1 \\
\hline 9 & -1 & -1 & -1 & 1 \\
\hline 10 & 1 & -1 & -1 & 1 \\
\hline 11 & -1 & 1 & -1 & 1 \\
\hline 12 & 1 & 1 & -1 & 1 \\
\hline 13 & -1 & -1 & 1 & 1 \\
\hline 14 & 1 & -1 & 1 & 1 \\
\hline 15 & -1 & 1 & 1 & 1 \\
\hline 16 & 1 & 1 & 1 & 1 \\
\hline 17 & -2 & 0 & 0 & 0 \\
\hline 18 & 2 & 0 & 0 & 0 \\
\hline 19 & 0 & -2 & 0 & 0 \\
\hline
\end{tabular}

\begin{tabular}{|l|l|l|l|l|}
\hline 20 & 0 & 2 & 0 & 0 \\
\hline 21 & 0 & 0 & -2 & 0 \\
\hline 22 & 0 & 0 & 2 & 0 \\
\hline 23 & 0 & 0 & 0 & -2 \\
\hline 24 & 0 & 0 & 0 & 2 \\
\hline 25 & 0 & 0 & 0 & 0 \\
\hline 26 & 0 & 0 & 0 & 0 \\
\hline 27 & 0 & 0 & 0 & 0 \\
\hline 28 & 0 & 0 & 0 & 0 \\
\hline 29 & 0 & 0 & 0 & 0 \\
\hline 30 & 0 & 0 & 0 & 0 \\
\hline
\end{tabular}

The workpiece SG Iron 450/12 grade is given by Hindustan Malleable \& Forging Ltd., Dhanbad, India. Machining was carried out at IDTR-Jamshedpur, Jharkhand, India. The chemical composition of the material is given in Table- 3 . The microstructure of the workpiece material captured by JEOL 5600 Scanning Electron Microscope is shown in Figure.1

Table-3: Work piece Chemical Compositions

\begin{tabular}{|l|l|l|l|l|l|l|l|}
\hline$\% \mathrm{C}$ & $\begin{array}{l}\% \\
\mathrm{Si}\end{array}$ & $\begin{array}{l}\% \\
\mathrm{Mn}\end{array}$ & $\begin{array}{l}\% \\
\mathrm{Mg}\end{array}$ & $\% \mathrm{~S}$ & $\% \mathrm{P}$ & $\% \mathrm{Fe}$ & $\begin{array}{l}\% \\
\text { Others }\end{array}$ \\
\hline 3.36 & 2.39 & 0.238 & 0.085 & $<0.15$ & 0.07 & 90.75 & 2.947 \\
\hline
\end{tabular}

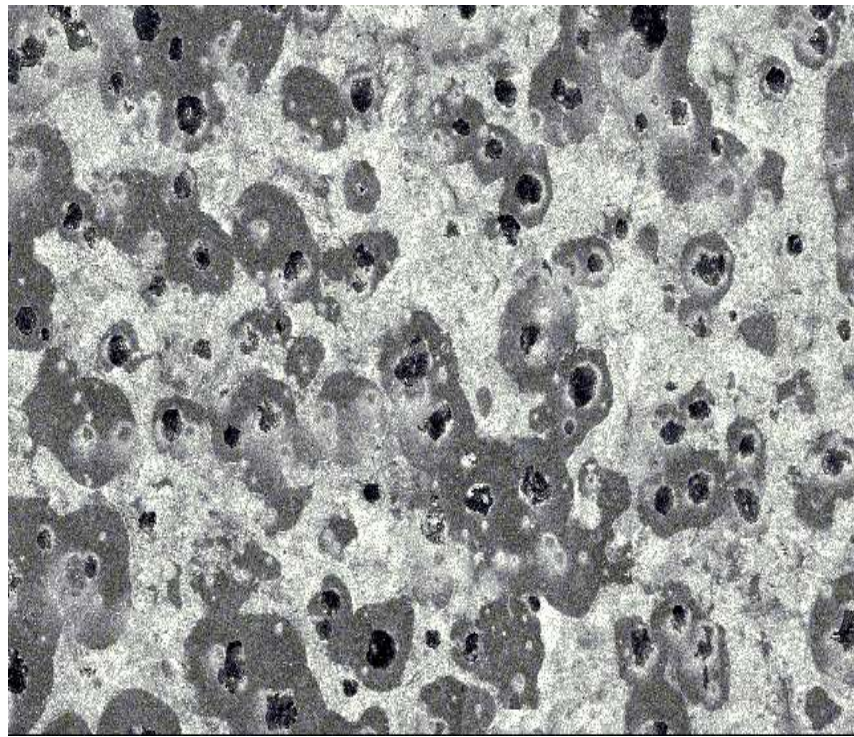

Fig -1: Magnification 100X

EDM Machine Agietron $250 \mathrm{C}$ is used along with a round copper tool of diameter $20 \mathrm{~mm}$. The dielectric fluid used for machining is Castrol SE 180 EDM Fluid.

As per the design matrix developed, 30 experiments are conducted in a random manner. From the experimental results, second order polynomial equations are generated for $\mathrm{S}_{\mathbf{q}}, \mathrm{S}_{\mathbf{s k}}, \mathrm{S}_{\mathbf{k u}}$ and $\mathrm{S}_{\mathbf{H t p}}$ by using The Design Expert ${ }^{\circledR}$ (Version 9.0.4.1) [17] software. The generated polynomial equation model is given below.

$$
\mathrm{Y}=\beta_{0}+\beta_{1} \mathrm{~A}+\beta_{2} \mathrm{~B}+\beta_{3} \mathrm{C}+\beta_{4} \mathrm{D}+\beta_{11} \mathrm{~A}^{2}+\beta_{22} \mathrm{~B}^{2}+\beta_{33} \mathrm{C}^{2}+
$$$$
\beta_{44} D^{2}+\beta_{12} A B+\beta_{13} A C+\beta_{14} A D+\beta_{23} B C+\beta_{24} B D+\beta_{34} C D
$$ 
Where, $\boldsymbol{\beta}$ 's are regression coefficients and A, B, C and D are the EDM process parameters mentioned earlier in TableI. The analysis of variance (ANOVA) technique is used to check the adequacy of the developed models at $95 \%$ confidence level. F Ratio's $_{\text {'s }}$ of the models developed are calculated and are compared with the corresponding tabulated values for $95 \%$ level of confidence. If the calculated values of $F_{\text {Ratio }}$ did not exceed the corresponding tabulated value then the model is considered adequate. The goodness of fit of the models are tested by calculating $\mathrm{R}^{2}$, $\mathrm{R}^{2}$ (adjusted) and $\mathrm{R}_{\text {(predicted). The coefficients of the models }}^{2}$ developed and model statistics are given in Table- 4 .

To check the adequacy of the models developed, two extra validation runs are carried out at different levels within the design space. The measured values of surface roughness parameters along with machining conditions are given in Table-5. A 95\% confidence interval (CI) is calculated based on the following equation. [18]

$$
\mathbf{C I}=\mathbf{X}_{0} \beta \pm \operatorname{SQR}\left(\mathbf{F}_{(1, \mathrm{n}-\mathrm{p})} * \operatorname{Sr}^{2}\left\{1+\left[\mathbf{X}_{0}\left(X^{\prime} X^{)^{-1}} \mathbf{X}_{0}{ }^{\prime}\right]\right\}\right)\right.
$$

Where, $\mathrm{X}_{\mathbf{0}}=$ Coded value of particular point $\left(1, \mathrm{X}_{\mathbf{0 1}} \mathrm{X}_{\mathbf{0 2}}, \mathrm{X}_{\mathbf{0 3}}\right.$, $\left.X_{04}\right)^{\prime}, S Q R=$ square root of the expression, $X=\left(n^{*} p\right)$ matrix of the levels of the independent variables,

$X^{\prime}=$ transpose of $X, X_{0}{ }^{\prime}=$ transpose of $X_{0}, S_{r}=$ mean square of residual.

Table-4: The Coefficients of the Models Developed and the Statistical Model Parameters for Surface texture parameters

\begin{tabular}{|c|c|c|c|c|c|}
\hline & \multicolumn{5}{|c|}{ Surface Texture Parameters } \\
\hline & & $\mathbf{S}_{\mathbf{q}}$ & $\mathbf{S}_{\mathrm{sk}}$ & $\mathbf{S}_{\mathrm{ku}}$ & $\mathbf{S}_{\mathrm{Htp}}$ \\
\hline \multirow{20}{*}{ 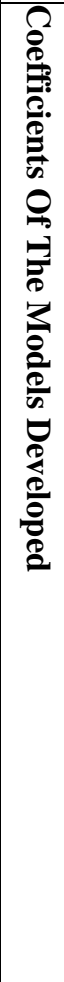 } & $\mathrm{B}_{0}$ & 8.36 & 0.358667 & 2.833333 & 13.98 \\
\hline & $\mathrm{B}_{1}$ & 1.78 & 0.111325 & 0.1975 & 3.42 \\
\hline & $\mathrm{B}_{2}$ & 3.48 & -0.03664 & 0.291667 & 5.96 \\
\hline & $\mathrm{B}_{3}$ & 0.4 & 0.008667 & -0.01167 & 1.07 \\
\hline & $\mathrm{B}_{4}$ & -0.051 & -0.03416 & -0.09917 & -0.061 \\
\hline & $\mathrm{B}_{11}$ & -0.22 & -0.071 & 0.054583 & -0.42 \\
\hline & $\mathrm{B}_{22}$ & 0.47 & -0.05087 & -0.04042 & 1.81 \\
\hline & $\mathrm{B}_{33}$ & -0.36 & -0.12433 & 0.175833 & -0.63 \\
\hline & $\mathrm{B}_{44}$ & 0.25 & -0.03637 & 0.092083 & -0.29 \\
\hline & $\mathrm{B}_{12}$ & 0.96 & 0.120413 & 0.24 & 2.22 \\
\hline & $\mathrm{B}_{13}$ & -0.32 & 0.008138 & -0.00375 & 0.016 \\
\hline & $\mathrm{B}_{14}$ & 0.029 & -0.06186 & -0.27125 & 0.36 \\
\hline & $\mathrm{B}_{23}$ & -0.082 & 0.086013 & 0.0325 & -0.17 \\
\hline & $\mathrm{B}_{24}$ & 0.069 & -0.03579 & -0.1325 & 0.59 \\
\hline & $\mathrm{B}_{34}$ & -0.05 & 0.119538 & 0.03125 & 0.4 \\
\hline & $\mathbf{F}_{\text {Ratio }}$ & 2.93 & 0.24162 & 0.41382 & 2.5 \\
\hline & $\sigma_{(\text {mean) }}^{2}$ & 0.3 & 0.01521 & 0.04555 & 1.03 \\
\hline & $\mathbf{R}^{2}$ & 97.5 & 93.2 & 94.22 & 97.81 \\
\hline & $\mathbf{R}^{2}{ }_{\text {(adj) }}$ & 95.17 & 86.86 & 88.82 & 95.77 \\
\hline & $\mathbf{R}_{\text {(pred) }}$ & 87.18 & 80.64 & 80.36 & 88.99 \\
\hline
\end{tabular}

From the Table-5, it is clear that the experimental values are within the $95 \%$ confidence interval of predicted values obtained from the developed models.

Table-5: Validation Runs and their results within 95\% Confidence interval for the developed Models.

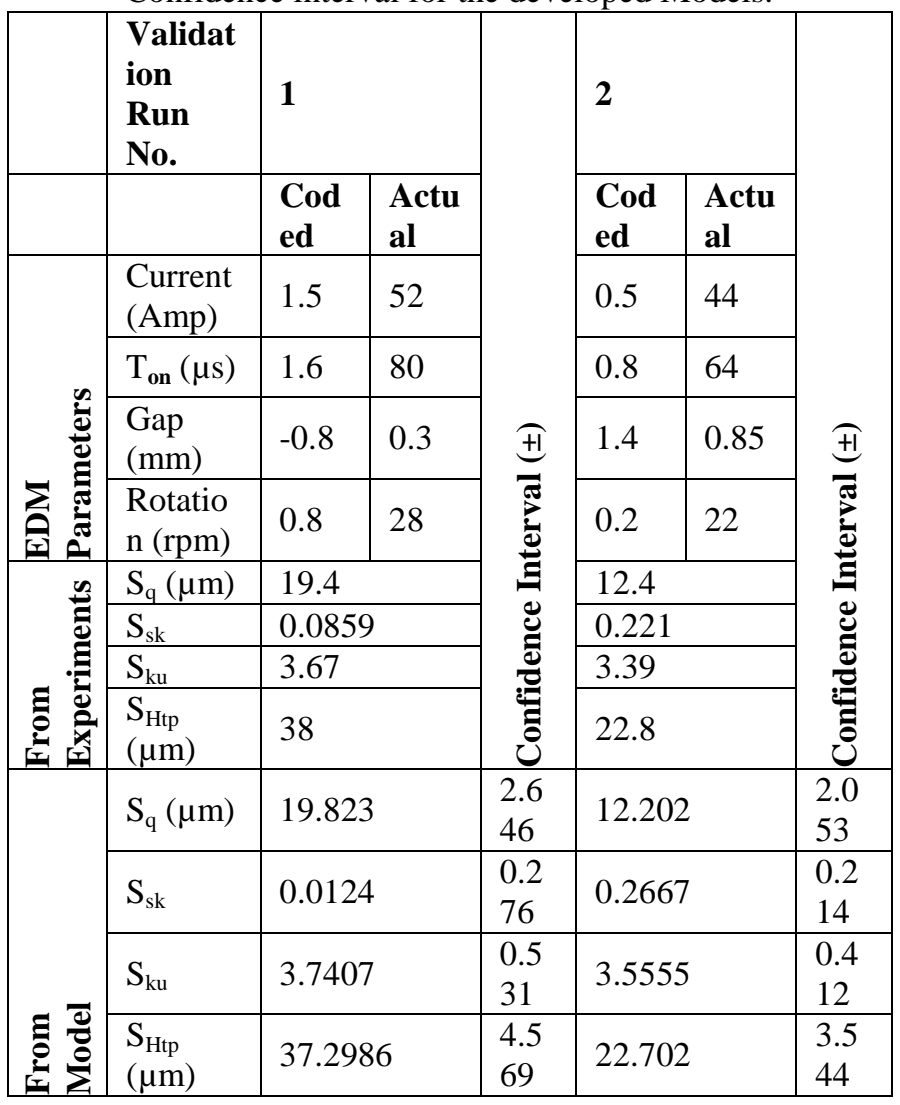

The Design Expert ${ }^{\circledR}$ V.9 [17] software is used for finding the optimum ranges of process variables for both lubricated and un-lubricated case. This software uses the desirability function for optimization [17]. Desirability function was proposed by G. Derringer and R. Suich [19]. In this method each response function is transformed into a desirability function. For calculating the desirability function of three different conditions such as larger-the-better, smaller-thebetter and nominal-is-best, three different criteria were suggested by Derringer and Suich $[19,16]$. They are as follows:

2.1. Larger -the- Better: (for maximizes the response)

$$
\operatorname{di}(x)=\left\{\begin{array}{cc}
0 & Y i(x)<L \\
{\left[\frac{Y i(x)-L}{T-L}\right]^{r}} & L \leq Y i(x) \leq T \\
1 & Y i(x)>T
\end{array}\right.
$$

2.2. Smaller-the- Better: (for minimizes the response)

$$
\operatorname{di}(x)=\left\{\begin{array}{cc}
1 & Y i(x)<T \\
{\left[\frac{U-Y i(x)}{U-T}\right]^{r}} & T \leq Y i(x) \leq U \\
0 & Y i(x)>U
\end{array}\right.
$$


2.3. Target-is-Best: (The two sided desirability function)

$$
\operatorname{di}(x)=\left\{\begin{array}{cc}
{\left[\begin{array}{cc}
0 & Y i(x)<L \\
T-L
\end{array}\right]^{Y i(x)-L}} & L \leq Y i(x) \leq T \\
{\left[\frac{U-Y i(x)}{U-T}\right]^{t}} & T \leq Y i(x) \leq U \\
0 & Y i(x)>U
\end{array}\right.
$$

Where $\mathrm{L}$ is the minimum allowable value (lower limit), $\mathrm{T}$ is the satisfactory value (target value) and $U$ is the upper limit of response, $Y_{i}(x), r, s$ and $t$ are arbitrary positive constants. They are called as weights. Usually $r=1$ is used in practice. A measure of the overall desirability (D) of the responses is obtained by using the geometric mean of the individual desirability functions as given in equation below.

$$
\mathrm{D}(\mathrm{x})=\left[\mathrm{d}_{1}(\mathrm{x}) * \mathrm{~d}_{2}(\mathrm{x}) * \ldots \ldots . . * \mathrm{~d}_{\mathrm{m}}(\mathrm{x})\right]^{1 / \mathrm{m}},
$$

Where, $m=$ number of parameters.

The overall desirability (D) is then maximized over the region of interest to give highest desirability value and the parameter combination which gives the highest desirability value is chosen as the optimum combination. Normally the desirability value varies between $0-1$.

The Design Expert ${ }^{\circledR}$ V.9 [17] software used for calculating the overall desirability function takes into consideration of the following factors.

- Range of the process variables: the range i.e. the minimum limit and maximum limit of each variable.

- Weights assigned to the variables: Usually taken as 1 for both lower and upper weights.

- Relative importance of the variables: denotes relative significance of each variable. A value of one to five can be assigned to each variable. In this study all the variables are given equal importance of ' 3 '.

Table $6 \& 7$ show values of different variables used for calculating overall desirability vale (D) for Un-lubricated and Lubricated cases respectively.

Table- 6: The conditions for un-lubricated (dry) case.

\begin{tabular}{|c|c|c|c|c|c|c|}
\hline time & $e$ & & & & & \\
\hline $\begin{array}{l}\text { Elect } \\
\text { rode } \\
\text { gap }\end{array}$ & $\begin{array}{l}\text { Is in } \\
\text { rang } \\
e\end{array}$ & -2 & 2 & 1 & 1 & 3 \\
\hline $\begin{array}{l}\text { Rotat } \\
\text { ion }\end{array}$ & $\begin{array}{l}\text { Is in } \\
\text { rang } \\
e\end{array}$ & -2 & 2 & 1 & 1 & 3 \\
\hline$S_{q}$ & $\begin{array}{l}\text { Maxi } \\
\text { mize }\end{array}$ & 3.32 & 18.1 & 1 & 1 & 3 \\
\hline$S_{s k}$ & $\begin{array}{l}\text { Mini } \\
\text { mize }\end{array}$ & $\begin{array}{l}- \\
0.393\end{array}$ & $\begin{array}{l}0.53 \\
5\end{array}$ & 1 & 1 & 3 \\
\hline$S_{k u}$ & $\begin{array}{l}\text { Mini } \\
\text { mize }\end{array}$ & 2.17 & 4.53 & 1 & 1 & 3 \\
\hline$S_{H t p}$ & $\begin{array}{l}\text { Maxi } \\
\text { mize }\end{array}$ & 5.38 & 34.6 & 1 & 1 & 3 \\
\hline
\end{tabular}

\begin{tabular}{|l|l|l|l|l|l|l|}
\hline $\begin{array}{l}\text { Nam } \\
\boldsymbol{e}\end{array}$ & Goal & $\begin{array}{l}\text { Lowe } \\
\boldsymbol{r} \\
\text { Limit }\end{array}$ & $\begin{array}{l}\text { Upp } \\
\boldsymbol{e r} \\
\text { Limi } \\
\boldsymbol{t}\end{array}$ & $\begin{array}{l}\text { Lowe } \\
\boldsymbol{r} \\
\text { weigh } \\
\boldsymbol{t}\end{array}$ & $\begin{array}{l}\text { Uppe } \\
\boldsymbol{r} \\
\text { weigh } \\
\boldsymbol{t}\end{array}$ & $\begin{array}{l}\text { Imp } \\
\text { orta } \\
\text { nce }\end{array}$ \\
\hline $\begin{array}{l}\text { Curr } \\
\text { ent }\end{array}$ & $\begin{array}{l}\text { Is in } \\
\text { rang } \\
\text { e }\end{array}$ & -2 & 2 & 1 & 1 & 3 \\
\hline $\begin{array}{l}\text { Pulse } \\
\text { on }\end{array}$ & $\begin{array}{l}\text { Is in } \\
\text { rang }\end{array}$ & -2 & 2 & 1 & 1 & 3 \\
\hline
\end{tabular}

\begin{tabular}{|c|c|c|c|c|c|c|}
\hline $\begin{array}{l}\text { Nam } \\
e\end{array}$ & Goal & $\begin{array}{l}\text { Lowe } \\
r \\
\text { Limit }\end{array}$ & $\begin{array}{l}\text { Upp } \\
\text { er } \\
\text { Limi } \\
t\end{array}$ & $\begin{array}{l}\text { Lowe } \\
r \\
\text { weigh } \\
t\end{array}$ & $\begin{array}{l}\text { Uppe } \\
r \\
\text { weigh } \\
t\end{array}$ & $\begin{array}{l}\text { Imp } \\
\text { orta } \\
\text { nce }\end{array}$ \\
\hline $\begin{array}{l}\text { Curr } \\
\text { ent }\end{array}$ & $\begin{array}{l}\text { is in } \\
\text { range }\end{array}$ & -2 & 2 & 1 & 1 & 3 \\
\hline $\begin{array}{l}\text { Pulse } \\
\text { on } \\
\text { time }\end{array}$ & $\begin{array}{l}\text { is in } \\
\text { range }\end{array}$ & -2 & 2 & 1 & 1 & 3 \\
\hline $\begin{array}{l}\text { Elect } \\
\text { rode } \\
\text { gap }\end{array}$ & $\begin{array}{l}\text { is in } \\
\text { range }\end{array}$ & -2 & 2 & 1 & 1 & 3 \\
\hline $\begin{array}{l}\text { Rotat } \\
\text { ion }\end{array}$ & $\begin{array}{l}\text { is in } \\
\text { range }\end{array}$ & -2 & 2 & 1 & 1 & 3 \\
\hline$S_{q}$ & $\begin{array}{l}\text { mini } \\
\text { mize }\end{array}$ & 3.32 & 18.1 & 1 & 1 & 3 \\
\hline$S_{s k}$ & $\begin{array}{l}\text { mini } \\
\text { mize }\end{array}$ & $\begin{array}{l}- \\
0.393\end{array}$ & $\begin{array}{l}0.53 \\
5\end{array}$ & 1 & 1 & 3 \\
\hline$S_{k u}$ & $\begin{array}{l}\operatorname{maxi} \\
\operatorname{mize}\end{array}$ & 2.17 & 4.53 & 1 & 1 & 3 \\
\hline$S_{H t p}$ & $\begin{array}{l}\text { mini } \\
\text { mize }\end{array}$ & 5.38 & 34.6 & 1 & 1 & 3 \\
\hline
\end{tabular}

Table-7: The conditions for lubricated case

\section{RESULTS AND DISCUSSIONS}

- Un-lubricated / dry Condition: Table-8 shows the values of the process parameters which give the highest desirability value for un-lubricated / dry condition. The highest desirability value obtained for minimum wear in dry condition is 0.913 corresponding to the coded process parameter values of current $=0.112$, Pulse on time $=2$, electrode gap $=-0.312$ and rotation=2. The optimum values of the surface parameters are $\mathrm{S}_{\mathrm{q}}=18.705, \mathrm{~S}_{\mathrm{sk}}=-0.393, \mathrm{~S}_{\mathrm{ku}}=2.892$ and $\mathrm{S}_{\mathrm{Htp}}=34.600$.

Table-8: Optimized Parameters for Dry case

\begin{tabular}{|l|l|l|l|l|l|l|l|l|}
\hline Current & Pulse on time & Electrode Gap & Rotation & $S_{\mathbf{q}}$ & $S_{\text {sk }}$ & $S_{\text {ku }}$ & $S_{\text {Htp }}$ & D \\
\hline $\mathbf{0 . 1 1 2}$ & $\mathbf{2 . 0 0 0}$ & $\mathbf{- 0 . 3 1 2}$ & $\mathbf{2 . 0 0 0}$ & $\mathbf{1 8 . 7 0 5}$ & $\mathbf{- 0 . 3 9 3}$ & $\mathbf{2 . 8 9 2}$ & $\mathbf{3 4 . 6 0}$ & $\mathbf{0 . 9 1 3}$ \\
\hline
\end{tabular}


Figure. 2 shows the contour curves for overall desirability values. From the figure, it is clear that a number of combinations of process parameters may yield a high value (D>0.9). Larger the region for $\mathrm{D}>0.9$ easier it is to realize it. It is important to note that the optimum values of process parameters will have confidence intervals. The 95\% confidence interval (CI) may be calculated using the equation referred above.

- Table-9 shows the values of the process parameters which give the highest desirability value for lubricated condition. The desirability value obtained for minimum wear in Lubricated condition is 0.935 corresponding to the coded process parameter values of current $=1.995$, Pulse on time $=-1.056$, electrode gap $=1.999$ and rotation $=-2.000$.The optimum values of the surface parameters are $\mathrm{S}_{\mathbf{q}}=5.412, \mathrm{~S}_{\mathrm{sk}}=-0.986, \mathrm{~S}_{\mathrm{ku}}=4.426$ and $\mathrm{S}_{\mathrm{Htp}}=7.349$.

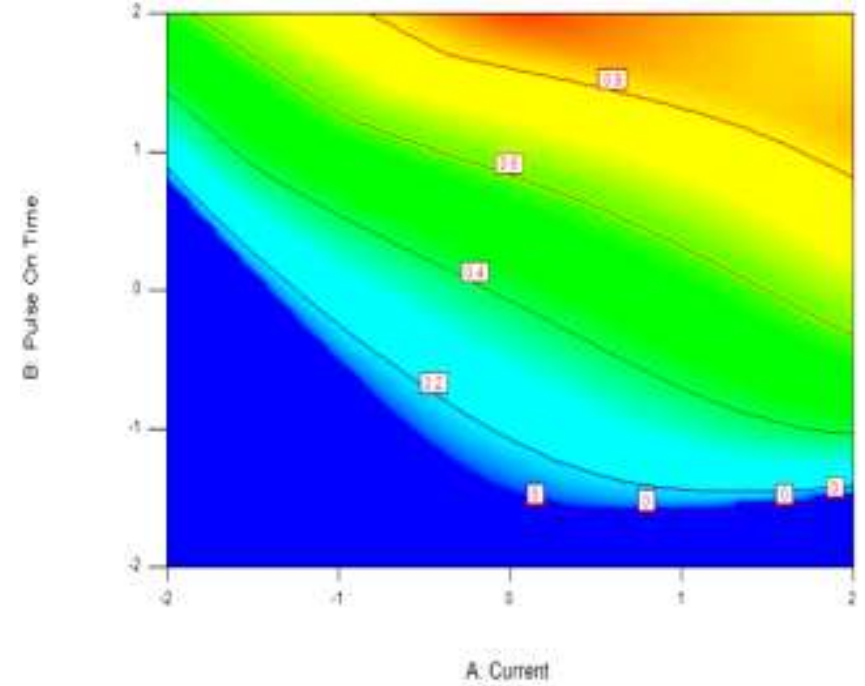

Fig-2: Contour graph for Desirability

Table-9: Optimized Parameters for lubricated case

\begin{tabular}{|l|l|l|l|l|l|l|l|l|}
\hline Current & Pulse on time & Electrode Gap & Rotation & $S_{\mathbf{q}}$ & $S_{\text {sk }}$ & $S_{\text {ku }}$ & $S_{\text {Htp }}$ & D \\
\hline $\mathbf{1 . 9 9 5}$ & $\mathbf{- 1 . 0 5 6}$ & $\mathbf{1 . 9 9 9}$ & $\mathbf{- 2 . 0 0 0}$ & $\mathbf{5 . 4 1 2}$ & $\mathbf{- 0 . 9 8 6}$ & $\mathbf{4 . 4 2 6}$ & $\mathbf{7 . 3 4 9}$ & $\mathbf{0 . 9 3 5}$ \\
\hline
\end{tabular}

Figure. 3 shows the contour curves for overall desirability values. From the figure, it is clear that a number of combinations of process parameters may yield a high value (D>0.9).

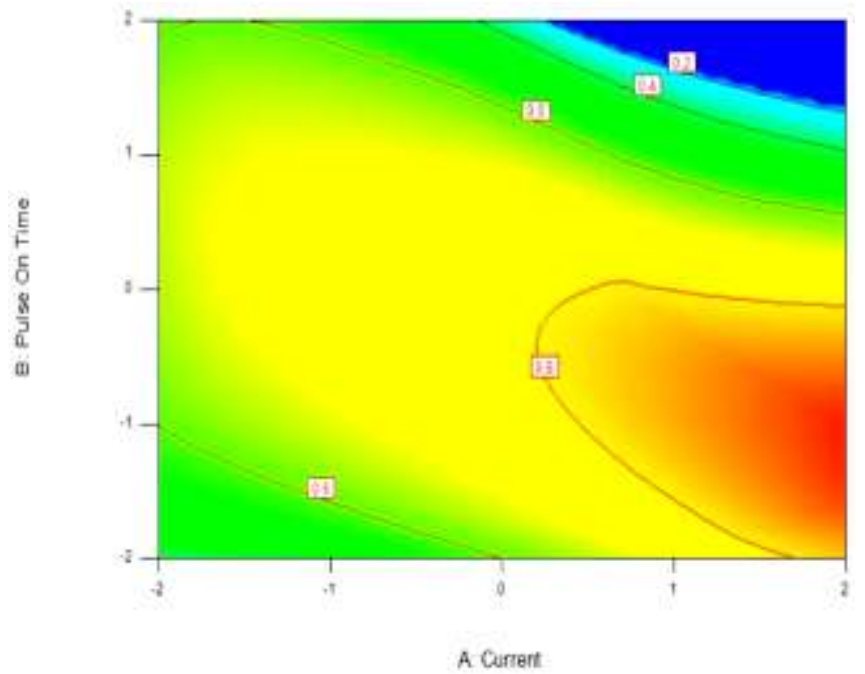

Fig-3: Contour graph for Desirability

As all the surface roughness parameters obtained in validation runs (Table-5) are within the predicted range of 95\% confidence level, it may be assumed that the optimum values of surface roughness parameters predicted by desirability functions can be realized.

\section{CONCLUSION}

- Mathematical models based on Central composite design have been developed to predict the effect of process variables on surface texture parameters $\left(\mathrm{S}_{\mathbf{q}}, \mathrm{S}_{\mathbf{s k}}\right.$, $\mathrm{S}_{\mathrm{ku}}$ and $\left.\mathrm{S}_{\mathbf{H t p}}\right)$
- The desirability value obtained for minimum wear in dry condition is 0.913 corresponding to the coded process parameter values of current $=0.112$, Pulse on time $=2$, electrode gap $=-0.312$ and rotation $=2$. The optimum values of the surface parameters are $\mathrm{S}_{\mathbf{q}}=18.705, \mathrm{~S}_{\mathrm{sk}}=-0.393, \mathrm{~S}_{\mathrm{ku}}=2.892$ and $\mathrm{S}_{\mathbf{H t p}}=34.600$.

- The desirability value obtained for minimum wear in Lubricated condition is 0.935 corresponding to the coded process parameter values of current $=1.995$, Pulse on time $=-1.056$, electrode gap $=1.999$ and rotation $=-2.000$. The optimum values of the surface parameters are $\mathrm{S}_{\mathbf{q}}=5.412, \mathrm{~S}_{\mathrm{sk}}=-0.986, \mathrm{~S}_{\mathrm{ku}}=4.426$ and $\mathrm{S}_{\text {Htp }}=7.349$

- The Desirability approach used for multi criteria optimization is found to be efficient for finding the range of operating parameters that can be used for low wear conditions.

\section{REFERENCES}

[1]. S H Lee, X P Li, Study of the effect of machining parameters on the machining characteristics in electrical discharge machining of tungsten carbide, journal of materials processing technology,115(2001),pp- 344-358.

[2]. B.N. Özdemir and C. Özek, An investigation on machinability of nodular cast iron by WEDM, Int. J AdvManufTechnol, 2006, vol.28, 869-872.

[3]. H.S. Tomadi, M.A. Hassan, Z. Hamedon, L.R. Daud, A.G. Khalid, Analysis of the influence of EDM parameters on surface quality, material removal rate and electrode wear of tungsten carbide, proceedings of International Multi Conference Of Engineers and Computer Scientists, 2009, vol. II, IMECS 2009, March 18-20, Hong Kong.

[4]. K.M Kumar, P. Hariharan , Experimental Determination of Machining Responses in Machining Austempered Ductile Iron (ADI), International Conference on Design And 
Manufacturing, IConDM 2013, Procedia Engineering 64 (2013) 1495 - 1504.

[5]. A. Kumar, V. Kumar and J. Kumar, Prediction of Surface Roughness in Wire Discharge Machining (WEDM) Process Based on Response Surface Methodology, Int. J. Engineering and Technology, 2012, vol. 2, 708-719.

[6]. "Precision metal smiths, Inc. 1081, East $200^{\text {th }}$ Street, Cleveland, OH 44117,'2015.

[7]. Benardos P.G. and Vosniakos G.C., Predicting Surface Roughness in Machining, Int. Journal of Machine Tools \& Manufacture, vol. 43, (2003), 833-844.

[8]. Petropoulus G.P, Pandazaras C.N, Paulo Davim J, Surface Texture characterization and Evaluation Related to Machining, in Surface Integrity in Machining, Ed. Paulo Davim J, Springer,2010,37-66.

[9]. ChiffreL.De, Lonardo P, Trumpold H, Lucca D.A, Gosh G, Brown C.A, Raja J, Hansen H.N, Quantitative Characterization of Surface Texture, Ann. CIRP, ,2000,vol.49,635-652.

[10]. Ramasawmy H and Blunt L, 3D Surface Topology Assessment of the Effect of Different Electrolytes During Electrochemical Polishing of EDM Surfaces, Int. J. Machine Tools \&Manufacture, 2002,vol.42, 567-574.

[11]. Aris N.F.M, Cheng K, Characterization Of The Surface Functionality On Precision Machined Engineering Surfaces, Int. J. Adv. Manuf. Technol., 2008, Vol.38, 402409.

[12]. Deleanu L, Georgescu C and Suciu C, A Comparison Between 2D And 3D Surface Parameters For Evaluating The Quality Of Surfaces, The Annals of "Dunarea De Jos" University of Galati", ISSN 1221-4566 ,2012,pp.5-12.

[13]. Grabon W, Pawlus P, Sep J, Tribological Characteristics of One-Process and Two-Process Cylinder Liner Honed Surfaces Under Reciprocating Sliding Conditions, Tribology International ,2010, vol.43,18821892.

[14]. Sedlaček M, PodgornikB,Vižintin, Influence of Surface Preparation on Roughness Parameters, Friction and Wear, Wear, 2009, vol.266, 482-487.

[15]. Bishnu.M.Jha\& A. Mandal, Multicriteria Optimization of Surface Roughness Produced in Electro Chemical Machining, International Journal of Engineering Research \& Technology (IJERT), Vol.3 Issue 6, June - 2014. ISSN: 2278-0181.

[16]. Montgomery D.C., Design and Analysis of Experiments, Ed.5th, Wiley India Pvt. Ltd., N. Delhi, 427,417-419,458-459,448-454.

[17]. Design-Expert V9 ${ }^{\circledR}$-product of M/s Stat - Ease Inc.

[18]. Deming S.N. and Morgan S.L., Experimental Design A Chemometric Approach, 1987, Elsevier, Netherlands, 171-173.

[19]. George Derringer, Ronald Suich, Simultaneous Optimization of Several Response Variables, Journal of Quality Technology, Vol. 12, No. 4, October 1980, pp.214219. 